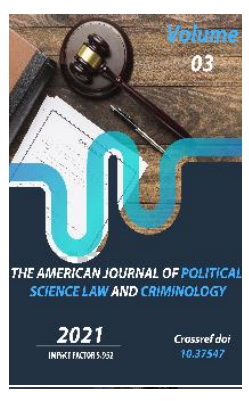

\title{
Legal Basis Of The Formation Of The Activities Of Non- Governmental Non-Profit Organizations In Uzbekistan
}

\section{Shirinov J.J.}

Applicant For The Tashkent State University Of Law, Uzbekistan

Journal Website: http://usajournalshub.c om/index,php/tajpslc

Copyright: Original content from this work may be used under the terms of the creative commons attributes 4.0 licence.

\section{ABSTRACT}

In the given article was analyzed the legal basis for organizing the activities of non-governmental nonprofit organizations, describes the methods and process of their establishment, defines the legal concepts of the organizational and legal form and registration of non-governmental non-profit organizations, and elaborates scientifically based proposals and recommendations for improving legislation in this area.

\section{KEYWORDS}

Non-governmental non-profit organization, creation, founder, member, participant, initiator, legal entity, reorganization, organizational and legal form, registration, constituent documents.

\section{INTRODUCTION}

After Uzbekistan gained independence, significant work has been done to expand the participation of non-governmental non-profit organizations in all spheres of public life. Legal guarantees for the activities of public associations are enshrined in the Constitution of the country [1]. A legislative framework has been created that meets the generally 
recognized norms and principles of international law, aimed at creating the necessary conditions for the effective operation of non-governmental non-profit organizations. More than 200 acts of legislation have been adopted in the development of civil society institutions.

Thus, in 2009, a special Law "On Non-State Non-Commercial Organizations" was adopted. In accordance with item 15 of this Law, a nongovernmental non-profit organization is considered to be created from the moment of its state registration [2].

Before the state registration of a nongovernmental non-profit organization, there are important stages that are not disclosed in detail in national legislation. In particular, the very process of establishing a nongovernmental non-profit organization is not regulated in detail.

Uzbekistan's national legislation defines "founders", "members", "participants" and "initiators" as subjects authorized to create non-governmental non-profit organizations. However, the main difference between these listed subjects and who of them can become a true founder was not reflected in the laws.

Some legal scholars have critically analyzed the fact that in the legislation regulating the activities of non-governmental non-profit organizations, the concepts of "participant" and "member of an organization" do not differ from each other, but are used as synonyms [3].

According to N.V. Kozlova, public organizations and political parties have their founders and members, but do not have members. On the other hand, mass social movements, public foundations and public institutions have only their founders and participants and do not have members [4].

Having studied the scientific views of a number of scientists, one can draw conclusions:

Firstly, in the process of creating a nongovernmental non-profit organization, there are no members, therefore, membership is determined after the official establishment of the organization;

Secondly, a non-governmental non-profit organization is created only by its founders;

Thirdly, only non-governmental non-profit organizations in the form of public associations can be created by a "group of initiative citizens".

One of the methods of creating nongovernmental non-profit organizations is the reorganization of a legal entity. Reorganization of a legal entity is a set of actions that have legal significance, as a result of which one or more new legal entities are simultaneously created or one or more existing legal entities are terminated.

Thus, in contrast to the traditional method, when a non-governmental non-profit organization is created through reorganization, inheritance law arises. In this case, only a legal entity can act as the subject of reorganization. This means that some nongovernmental non-profit organizations cannot be created through the reorganization of a legal entity.

For example, it is known that a public association is created only on the initiative of individuals. Thus, the creation of a nongovernmental non-profit organization in the form of a public association through the reorganization of a legal entity is impossible. 
When a non-governmental non-profit organization is created by the decision of the majority of the founders, the protocol (decision) of the constituent assembly is a legal document confirming the fact of the creation of the organization, the approval of its constituent documents and the formation of governing bodies. Consequently, the constituent assembly must be held and formalized properly within the framework of the law.

However, in practice, difficulties arise, since the laws do not spell out general requirements for holding a constituent assembly. In particular, in practice, state registration of nongovernmental non-profit organizations is denied due to incorrect execution of the protocol (decision) of the constituent assembly. Therefore, the law must establish general requirements for the registration of the constituent assembly of a nongovernmental non-profit organization.

The choice of organizational and legal form is important when creating a legal entity. After all, it is the organizational and legal form of a legal entity that is one of the main criteria for dividing it into commercial and noncommercial organizations. In accordance with item 40 of the Civil Code of the Republic of Uzbekistan, a legal entity can be an organization pursuing profit-making (commercial organization) as the main goal of its activities, or not setting profit-making as such a goal (non-commercial organization) [5].

Although the term "legal form" is often used in legislation to refer to a legal entity, there is no legal definition of this term. According to some researchers, the organizational and legal form of a legal entity is a set of certain features and characteristics that distinguish it from one group of common features and distinguish one group of legal entities from another [6]. The organizational and legal form of a legal entity shows its organizational structure, the method of forming property, and the peculiarities of participation in civil law relations [7].

According to V.M. Kameneva, the organizational and legal form of a legal entity is a set of specific features that make it possible to identify it. Such signs may include the purpose and subject of the organization's activities, the subject composition of the founders (participants, members) and their rights to the property of a legal entity, as well as the procedure for using (distributing) property [8].

According to R. Utkin, the organizational and legal form of non-profit organizations is a set of features inherent in a certain group of organizations and necessary for their existence in the legal field: the purpose of the organization, relationships with persons participating in its activities [9].

In order to define the concept of the organizational and legal form of a nongovernmental non-profit organization, let us analyze its constituent features.

In particular, the focus is on the goal of a nongovernmental, non-profit organization. If the purpose of an organization is to protect the interests of its members, coordinate their activities, such organizations are created in the form of public associations, associations (unions) and other corporate forms.

Another important feature that helps to determine the organizational and legal form of a non-governmental non-profit organization is the legal status of the founders of the organization, which states that if the founders 
are legal entities, such an organization can be formed in the form of an association (union) or institution.

Another important feature of the organizational and legal form of a nongovernmental non-profit organization is the subjective structure of the organization. If an organization has membership and all members are individuals, such an organization can be formed in the form of a public association.

The next important feature of a nongovernmental non-profit organization is the peculiarities of property relations. For example, most non-governmental non-profit organizations do not require authorized capital to establish. However, the creation of public funds requires the availability of initial funds. In addition, for some membership-based organizations, membership fees are identified as one of the sources of property formation, and the public fund and public organization do not have membership fees [10].

Based on the foregoing, the following definition is proposed: the organizational and legal form of a non-governmental non-profit organization is a set of signs reflecting the purpose of the organization's activities, its subjective structure (membership or nonmembership) and property relations, as well as clarifying the legal status of its founders.

It remains difficult to determine the organizational and legal form of some nongovernmental non-profit organizations in Uzbekistan. For example, if only natural persons are united, such an organization can be created in the form of a public association, if only legal entities are united - in the form of an association of legal entities.
However, the organizational and legal form of a non-governmental non-profit organization, which consists of an association of both individuals and legal entities, and also coordinates their activities as a member, protects their rights and legitimate interests, remains undisclosed.

Therefore, it is proposed to legislatively consolidate the "association of individuals and legal entities" as a new organizational and legal form of a non-governmental non-profit organization.

Legal entities in the form of "institutions" are formed as two types, that is, "state" and "nonstate". Therefore, it is not recommended to use the same legal form for both sectors (government and non-government). In this regard, it is proposed to name an institution in the form of a non-governmental non-profit organization as a "public institution".

In addition, since a public institution is not a corporate organization, the law should clearly state that such a non-governmental non-profit organization is not membership-based. In this regard, we propose to define a public institution as a non-governmental non-profit organization that has no membership, formed by an individual and (or) legal entity or several persons to perform social, cultural and other functions of a non-profit nature.

In practice, depending on the founder of an organization in the form of an association (union), it is determined whether it belongs to a particular type of legal entity. For example, an association (union) created by non-profit organizations is registered as a nongovernmental non-profit organization. However, associations (unions) created by commercial organizations are not included in 
the register of non-governmental noncommercial organizations. Although, according to item 77 of the Civil Code of the Republic of Uzbekistan, an association (union) created by a commercial organization is also a non-commercial organization [5].

Therefore, an association (union) created by legal entities, including commercial organizations, must also be registered as a non-governmental non-profit organization.

In our opinion, the state registration of a nonstate non-profit organization is the fact of confirmation of the recognition by the state of a new subject of law by entering the relevant information into the state register by the authorized state body.

The main goals of state registration are: "filtering" from the appearance of destructive subjects; statistical accounting of nongovernmental non-profit organizations; the legitimacy of their activities.

An important role is played by the issue of payment of state fees for state registration of non-state non-profit organizations.

According to some scientists, the state fee paid for state registration should be divided into two parts. The first part is the state fee for the examination of documents, which is paid before submitting documents to the registration authority. The second part is the state fee for state registration, which is paid before the organization is included in the Unified State Register of Legal Entities after a positive decision of the registering authority [11].

In accordance with Article 3 of the Law of the Republic of Uzbekistan "On State Duty", the state duty is a mandatory payment charged for the commission of legally significant actions and (or) the issuance of documents by authorized institutions and (or) officials [12].

In our opinion, the collection of a state duty before a decision on state registration of a nonstate non-profit organization is made does not fully comply with the principle of fairness. Because the state fee should be charged for the commission of actions that have legal significance. Therefore, it is proposed to introduce into practice the payment of state fees after the registration authority makes a decision to register a non-state non-profit organization.

In most cases, registration of a nongovernmental non-profit organization is denied due to deficiencies in the constituent documents. However, in practice, the registration authority reveals further shortcomings in the re-submitted documents. That is, since the flaws in the documents were not fully indicated at the first refusal, they will be revealed during the subsequent examination. This creates bureaucratic barriers for state registration of a non-governmental non-profit organization.

Therefore, it is necessary to consolidate at the legislative level the norm according to which shortcomings in the submitted documents, which were not indicated in a timely manner due to the fault of the registering authority, cannot be the basis for repeated refusal of state registration of a non-governmental nonprofit organization.

\section{REFERENCES}

1. Constitution of the Republic of Uzbekistan $\neg$ Tashkent - "Uzbekistan" - 2017.

2. Law of the Republic of Uzbekistan "On non-governmental non-profit 
organizations" // Bulletin of the Oliy Majlis of the Republic of Uzbekistan, 1999, No. 5 , item 115

3. Sh.M. Asyanov, M.Sh. Kulikova, A. Isaeva // Guidelines for registration and activities of non-governmental non-profit organizations - T-2008. - p.58

4. Kozlova N.V. Legal personality of a legal entity. - M .: Statut, 2005 -- P.90

5. Civil Code of the Republic of Uzbekistan // Bulletin of the Oliy Majlis of the Republic of Uzbekistan, 1996, annex to No. 2

6. Civil law. Textbook. Volume 1 / Edited by A.L. Sergeyev, Yu.K. Tolstoy - 5th ed., Revised. and add. - M., PROSPECT, 2001.P. 173-174

7. Kostenko N.V. Civil law regulation of the activities of non-profit organizations in the Russian Federation / Diss. Cand. legal entity sciences. - OMSK, 2003. - p. 45

8. Kameneva V.M. "Legal regulation of the activities of non-profit organizations in the Russian Federation (administrative and financial aspects)" / author. Cand. jurid. sciences. - M: 2007 - P.14

9. R.V. Utkin Organizational and legal forms and types of non-profit organizations. Modern concept and prospects // Bulletin of the Ministry of Justice of the Russian Federation. 2002. No. 5 P.61

10. J. Shirinov Theoretical and legal issues of the organizational and legal form of nongovernmental non-profit organizations // Lawyer Bulletin No. 6, issue 1 / Tashkent2020. P.11

11. Kokoreva O.M., Legal regulation of state registration of non-profit organizations / Diss. legal entity Sciences - M: .2010. - p.57

12. Law of the Republic of Uzbekistan "On State Duty" // Narodnoe Slovo (The People's Word), January 7, 2020
13. Bekov I. Constitutional and legal basics for the participation of political parties in the formation of the Legislative Chamber of the Oliy Majlis //Journal of Critical Reviews. - 2020. - T. 7. - №. 11. - C. 1571-1577. 